\title{
Coastal Tourism Development Planning based on Community and Natural Resources in Pangandaran Regency
}

\author{
Marine Kenzi Martasuganda ${ }^{1}$, Boedi Tjahjono $^{2}$, Fredinan Yulianda $^{3}$ \\ ${ }^{1}$ Regional Planning, Department of Soil Sciences and Land Resources, Faculty of Agriculture, Bogor Agricultural University, \\ Meranti Street, IPB Darmaga Campus, Bogor 16680, West Java, Indonesia \\ ${ }^{2}$ Mitigation and Land Degradation, Department of Soil Sciences and Land Resources, Faculty of Agriculture, Bogor Agricultural \\ University, Meranti Street, IPB Darmaga Campus, Bogor 16680, West Java, Indonesia \\ ${ }^{3}$ Coastal and Ocean Resource Management, Department of Aquatic Resources Management, \\ LingkarAkademik Street No.1, Kampus IPB Darmaga Bogor 16680, West Java, Indonesia
}

\begin{abstract}
Tourism plays an important role in the development, as a source of foreign exchange and in expanding employment and business opportunities. This research was conducted in the coastal parts of Pangandaran Regency, which aims; to assess the suitability of coastal tourism, to assess the level of public acceptance in coastal areas development as tourism area, and to formulate coastal tourism direction.The results of this study showed that only some parts of coastal areas in Pangandaran Regency can be used as coastal tourism area. Those areas are located in the west of Pangandaran Village, Pananjung Village, Wonoharjo Village, and Cikambulan Village. The residents in those areas are accepting their areas to be developed as a coastal tourism area.
\end{abstract}

Keywords: coastal tourism, suitability for tourism,public participation, Pangandaran.

\section{Introduction}

Tourism is an alternative economic sector, which was deemed capable to accelerate the effort to tackle poverty in Indonesia [1]. In the national level, strengthening the role of tourism sector is expected to offernew opportunities for economic and socio-cultural development.Economically, tourism development brought beneficial impact related to employment opportunities in non-agricultural sector. This development will encourage the improvement in agricultural sector's contribution to the Gross Domestic Product (GDP).However, to make this happen, it required the community participation while developing the tourism areas. This is because, the management of natural resources cannot be separated from the open access tragedy that often causes the resource depression, economic inefficiency and social issues [2].

One of the potential tourism destinations, which gets good attention, is Pangandaran Regency, West Java Province. Pangandaran and its surrounding offer various tourism sites, namely nature tourism site, cultural tourism site, and special interest tourism site. However, from those various tourism sites in Pangandaran, nature tourism site-especially coastal tourism-is growing faster than the others [3].

Pangandaran Regency is a new district that was formerly a part of Ciamis Regency. The establishment as Pangandaran Regency is valid since 2012 through Act No. 21 of 2012 on the Establishment of Pangandaran Regency. One of the intensive program, which will be conducted by Pangandaran Regency Government, is the development in the field of tourism especially coastal tourism. Coastal tourism concept includes entertainment and leisure-oriented activities that occur in the coastal zone and coastal waters [4].
Tourism development is not only intended to strengthen the national economy, but it is also expected to play a role as a catalyst of development [5]. To strengthen that, the process of development needs community participation to be an important consideration in the decision-making and management of coastal and marine areas.

Therefore, tourism development planning should consider the potential of coastal natural resources and public acceptance in the development of coastal areas for coastal tourism activities. This is needed to formulate the directionof coastal tourism development in Pangandaran Regency.

\section{Methodology}

Research location in this study is shown in Figure (1). The region is located at coastal area in eight villages, namelyPangandaran, Pananjung, Wonoharjo, Cikambulan, Sukaresik, Cibenda, Ciliang, and Karangjaladri Village in Pangandaran Regency, West Java Province, Indonesia.

\subsection{Suitability Analysis for Coastal Tourism}

Coastal tourism is a tourism activity that promotes cultural and coastal resources, such as seashore leisure, beach sports, enjoying the scenery, resting, fishing, swimming and rowing boat.

The suitability of coastal tourism has considered 10 parameters that create 2 classifications assessment, suitable (S1) and quite suitable (S2). The parameters of coastal tourism suitability in recreation categories are the bathymetry, waters clarity,seabed materials, type and width of the beach, flow velocity, beach's slope, beach's land cover, dangerous organism, and freshwater availability [6]. 


\section{International Journal of Science and Research (IJSR) \\ ISSN (Online): 2319-7064}

Index Copernicus Value (2013): 6.14 | Impact Factor (2015): 6.391

Suitability matrix for coastal tourism, that used in this study, is shown in Table 1.

Table 1: Coastal Tourism Suitability Matrix

\begin{tabular}{|c|c|c|c|}
\hline \multirow{2}{*}{ No } & \multirow{2}{*}{ Parameter } & \multicolumn{2}{|c|}{ Category } \\
\cline { 3 - 4 } & S1 & S2 \\
\hline 1 & Bathymetry $(\mathrm{m})$ & $0-3$ & $>3-6$ \\
\hline 2 & Beach's Type & $\begin{array}{c}\text { White Sand } \\
\text { (Sandy Beach) }\end{array}$ & $\begin{array}{c}\text { White Sand } \\
\text { (Sandy Beach), a } \\
\text { bit of Coral }\end{array}$ \\
\hline 3 & Beach's Width $(\mathrm{m})$ & $>15$ & $15-10$ \\
\hline 4 & Seabed Materials & Sand & Sandy Coral \\
\hline 5 & Flow Velocity $(\mathrm{m} / \mathrm{s})$ & $0-0,17$ & $0,17-0,34$ \\
\hline 6 & Beach's Slope $\left({ }^{\circ}\right)$ & $<10$ & $25-10$ \\
\hline 7 & Waters Clarity $(\%)$ & $>80$ & $50-80$ \\
\hline 8 & Beach's Land Cover & $\begin{array}{c}\text { Coconut Trees, } \\
\text { Open Land }\end{array}$ & $\begin{array}{c}\text { Bush, Low } \\
\text { Shrubs,Savannah }\end{array}$ \\
\hline 9 & Dangerous Organism & Not Found & Sea Urchin \\
\hline 10 & $\begin{array}{c}\text { Freshwater Availability } \\
\text { (range/km) }\end{array}$ & $<0,5(\mathrm{~km})$ & $>0,5-1(\mathrm{~km})$ \\
\hline
\end{tabular}

Source: Yuliandaet al 2010

\subsection{Public Acceptability Analysis}

Community-based tourism is a tourism which is planned and managed by individuals/households groups. Those groups consists of the people as a communal business group. These activities also can be managed by a private company, of which agenda is prepared by the local community [7].

Moreover, the participation of local communities also can improve the decision-making process that leads to the resource utilization and efficiency. Community participation is also important to educate local people to be aware of potential disasters and to be more responsive to the rights, that they deserve [8].

According to that, to determine the level of public acceptance in Pangandaran Regency towards restructuring and development of tourism plan is necessary. It is line with community as a part of the environment, who will have direct contact and get the impact of the tourist.

In this study, the level of public acceptance in the development of coastal as a tourism area is measured by considering five parameters: area development as a tourism destination, tourism area management by local communities, community participation in tourism, the benefits of tourism activities, and the presence of tourists [9]. Whereas, for the classification assessment in this analysis is divided into two categories, high (S1) and quite high (S2).The rate level of public acceptance is shown in Table 2.
Table 2: Public Acceptance Matrix

\begin{tabular}{|c|c|c|c|}
\hline \multirow{2}{*}{ No } & Parameter & \multicolumn{2}{|c|}{ Category } \\
\cline { 3 - 4 } & S1 & S2 \\
\hline 1 & $\begin{array}{c}\text { Area Development as Tourism } \\
\text { Destination }\end{array}$ & Agree & $\begin{array}{c}\text { Somewhat } \\
\text { Disagree }\end{array}$ \\
\hline 2 & $\begin{array}{c}\text { Tourism Area Management by Local } \\
\text { Communities }\end{array}$ & Agree & $\begin{array}{c}\text { Somewhat } \\
\text { Disagree }\end{array}$ \\
\hline 3 & $\begin{array}{c}\text { Community Participation in Tourism } \\
\text { Activities }\end{array}$ & Good & Quite Good \\
\hline 4 & The Benefits of Tourism Activities & Good & Quite Good \\
\hline 5 & The Presence of Tourists & Willing & Less Willing \\
\hline
\end{tabular}

Source : Yusiana et al 2011

\subsection{Direction for Coastal Tourism Development}

After analyzing the suitability of coastal tourism and the level of public acceptance towards the development of coastal tourism areas, then the next step is analyzing the designated direction for coastal areas, which can be developed as a coastal tourism. That development directionis viewed spatially based on the result of combining the suitability of coastal tourism and the level of public acceptance.Thus, based on the results obtained, it can be seen which areas, that are feasible and can be prioritized in the coastal areas development as a tourism area in Pangandaran Regency.

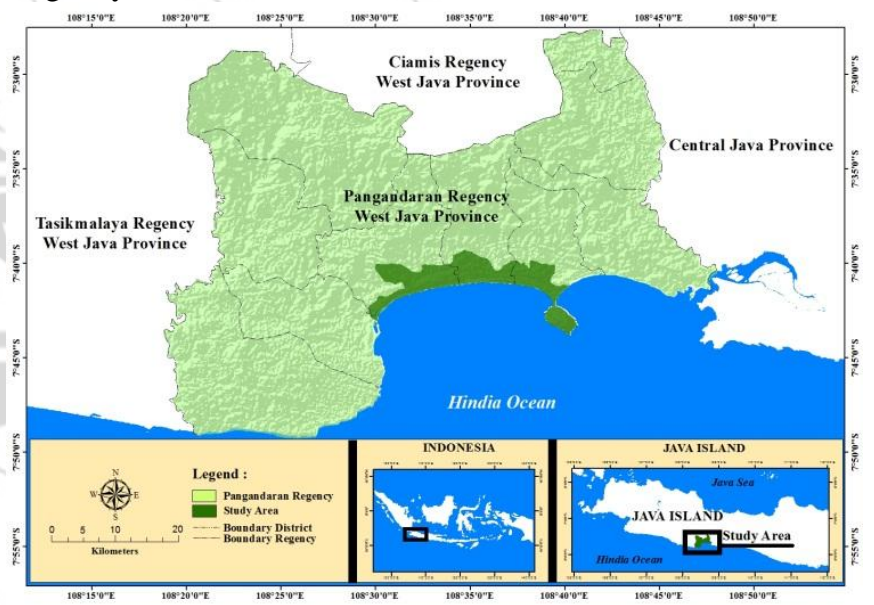

Figure 1: Location Map of Study Area

\section{Results and Discussion}

\subsection{Coastal Tourism Suitability}

According to the analysis results of coastal tourism suitability, which are shown in Figure 2, there are five of eight villages in this study that arepotential to be developed as coastal tourism. Four villages are categorized as suitable (S1), and one village is categorized as quite suitable (S2). The villages in suitable category (S1) are the West Coast of Pangandaran, Pananjung, Wonoharjo, and Cikambulan Village. While in the quite suitable category (S2) is Cibenda Village.These outcomes are rated by the rate of bathymethry and parameter of beach's type in those villages. The bathymethry is 3 meters and the beach's type is a sandy coastline except for Cibenda Village, which has a bit of coral. Furthermore, dangerous organism are not found in these villages. The width of the sandy coastline in those five villages ranges from 50-150 meters up to the land infrastructure, such as houses, shops, and roads [10]. Hence, 


\section{International Journal of Science and Research (IJSR) \\ ISSN (Online): 2319-7064}

Index Copernicus Value (2013): 6.14 | Impact Factor (2015): 6.391

those five villages have the availability of freshwater at a distance less than 500 meters from the shoreline, 0.2 kilometers precisely. Seabed materials in Pangandaran is the sand, of which size ranks from fine to very fine, including those that are part of the sand dunes [11].

The average flow velocity in Pangandaran Regency is 0.3$0.5 \mathrm{~m} / \mathrm{s}$. The beach's slope in these five villages is categorized as shallow of average $4^{0-} 8^{\circ}[12]$. The slope angle is also affected by the sand dunes that add mainland elevation on the coastline. The range of waters clarity in the south coastline Pangandaran Regency is 1-9 meters. The 9 meter grade is located in the tourism area in Batu Karas, Pangandaran, and Batu Hiu, while the 1 meter grade is located around the river mouth of Citanduy (during high sedimentation, that cause the water become very turbid).

The coastal land use in Pangandaran, Pananjung, Wonoharjo, and Cikambulan Village is mostly used as fishing boat parking, and souvenir and food stalls. In fact, the land use in those four villages is supposed to be a forest area that has function as coastal protection. This is different from the land use in Cibenda Village, which isdominated byshrubs land cover. This is because Cibenda Village is not the priority in coastal tourism development in Pangandaran Regency.

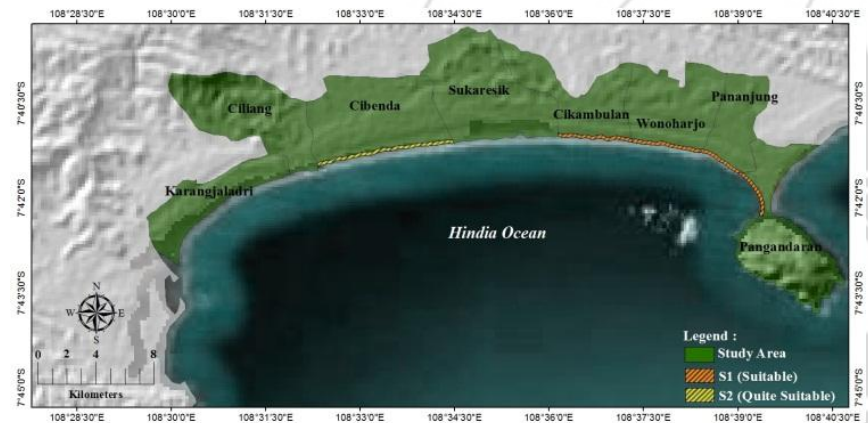

Figure 2: Dissemination of Coastal Tourism Area

\subsection{The Level of Public Acceptance}

Based on the level of community participation analysis, there are five villages categorized as high (S1) and one village categorized as quite high(S2). Those five villages in high category (S1) are Pangandaran, Pananjung, Wonoharjo, Cikambulan, and Ciliang Village. In general, the local people showed their eagerness if the government transforms their area to become a tourist destination and they strongly agree if the tourism management is conducted along with the local people. In this regard, that means the local people in these five villages agree with the presence of tourists.Community participation in those five villages is shown by the presence of Kelompok Penggerak Pariwisata (Kompepar) and the Local Working Group (LWG). Kompepar manages every Objek Daerah Tujuan Wisata (ODTW) in Pangandaran Regency.

Those community groups have their own roles in managing tourism activities in Pangandaran Regency. Kompepar can be found in each tourism sites, they accommodate smaller groups in every ODTW, such as tires, surfboards, and bikes rental organization, street vendors, and the others. Kompepar also acts as a mediator between local people and the government. As for the LWG focused on the environmental preservation in the Pangandaran Village.

As for quite highcategory (S2), it is Sukaresik Village. Just like the previous five villages, the local people are excited and agree to the presence of tourists. They also support their area to become a tourism area and the tourism managementis being managed by the local community. The exclusion of people from decision-making process and in Kompepar membership leads to the situation in which the role and benefits of tourism in Sukaresik Village becomes less facilitated by the local government.

Sukaresik Village has KarangTaruna as local youth organization of which members are enthusiastic in managing the well-known tourism areas, namely KarangTirta Beach. From the results of this analysis, then the level of public acceptance towards the coastal tourism development in the research area is spatially shown in Figure 3 by using village boundaries as unit analysis.

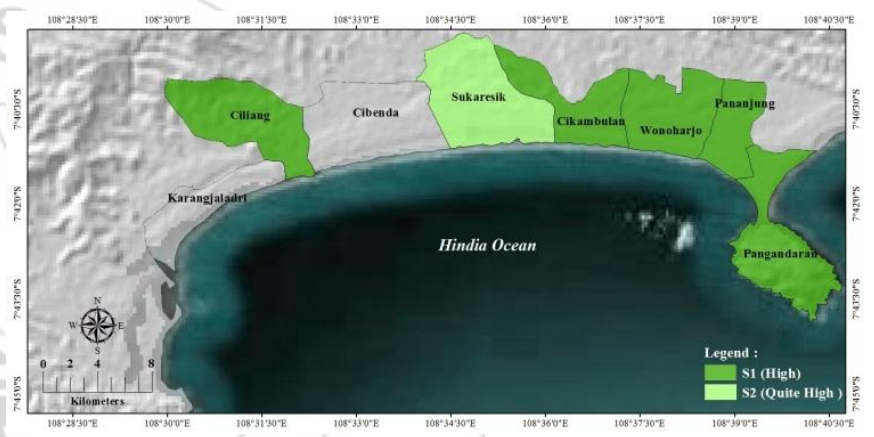

Figure 3. Level of Public Acceptance for Coastal Tourism Area

\subsection{Direction for Coastal Tourism Management}

A policy will implement its strategy, priorities, goals, objectives, and desired outcomes. In order to make an effective policy, it needs a "policy tools/instruments policy". The policy instrument is a step or action taken by the government to realize the established policy.Local Government of Pangandaran, with its vision "Pangandaran as Tourism Regency with Nature and Culture Internationalised Tourism Destinations and Comfortable Residence based on Religious Values", intends to develop its regional economy based on tourism activities. This development focuses on the use of coastal natural resources by establishing selected coastal areas that will be developed as coastal and maritime tourism region.

Direction of development for coastal tourism area, which is shown in Figure 4, was obtained by merging the coastal areas suitability classification for coastal tourism and public acceptance level classification with overlay analysis technique. The suitable developed areas as a coastal tourism area in Pangandaran Regency consists of four villages. Those villages are Pangandaran, Pananjung, Wonoharjo, and Cikambulan Village. 


\section{International Journal of Science and Research (IJSR) ISSN (Online): 2319-7064}

Index Copernicus Value (2013): 6.14 | Impact Factor (2015): 6.391

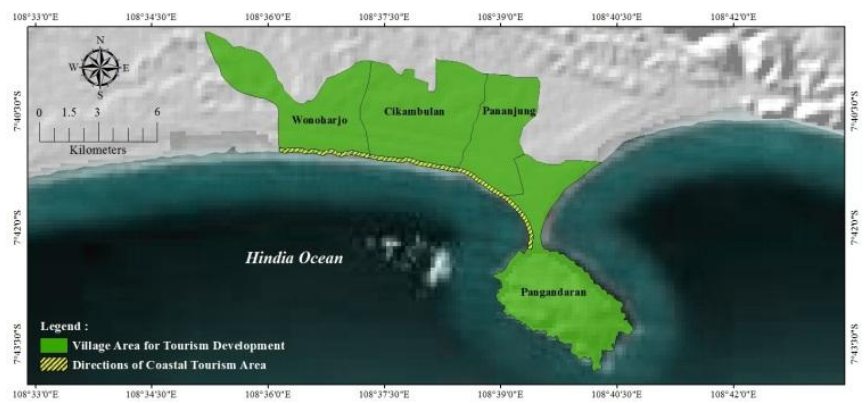

Figure 4: Recommendation for Coastal Tourism Development

\section{Conclusion}

Based on coastal tourism suitability analysis, the potential villages that can be developed as coastal tourism area are Pangandaran, Pananjung, Wonoharjo, and Cikambulan Village, while the potential villages based on the public acceptance level analysis are Pangandaran, Pananjung, Wonoharjo, Cikambulan, Ciliang, and Sukaresik Village. Therefore, the development direction for coastal tourism, based on the merger of two analysis results, can be conducted in four villages, namely Pangandaran, Pananjung, Wonoharjo, and Cikambulan Village.

\section{Recommendation}

Institutionalisation in the context of decentralization and autonomy in coastal resource management should be seen as a form of collaborative management on global, national, regional, and local scale. It aims to maximize the use of coastal areas potential in the best possible way. In the local scale, the coastal areas collaborative management should consider the rights of local people, local laws, institutions, and local wisdom as a form of community participation and self-reliance in the coastal tourism management.

The results of this study are expected to be taken into consideration for the Local Government of Pangandaran Regency as a sustainable coastal tourism management strategy and as an input in the spatial plan design and coastal areas zoning plan in Pangandaran Regency.

\section{References}

[1] Yoeti, O, A. Cultural Tourism Problems and Its Solution (In Indonesian), Pradnya Paramita Press, Jakarta, 2006.

[2] Yulianto, G. "Institutional Study of Land Rights in TelukBintuni Coastal Villages (In Indonesian)." BuletinEkonomiPerikanan. VIII (2), pp 82-89, 2008.

[3] Anggraini, D. "United Nations World Tourism Organization (UNWTO) and Indonesia Cooperation in Tourism Development in Pangandaran, West Java, 2011-2013," JOM FISIP, II (1), pp 1-15, 2015.

[4] Hall C, M. "Trend in Ocean and Coastal Tourism," Ocean \& Coastal Management 44 (p 601-618), 2001.

[5] Dhalyana, D. Adiwibowo, S. "Influencing Nature Tourism Park of Pangandaran to The Social Life of Local Communities (In Indonesian)" Journal of SosiologiPedesaan, I (3), pp 182-199, 2013.
[6] Yulianda, F., A. Fahrudin, A.A. Hutabarat, S. Harteti, Kusharjani, H.S. Kang, \& L. Adrianto. 2010. Coastal and marine management in an integrated (In Indonesian). $\quad$ PusdiklatKehutananDepartemenKehutanan RI, SECEM-Korea International Cooperation Agency, Bogor.

[7] Godde, P. "Community-based Mountain Tourism: Practices for Linking Conservation with Enterprise," Synthesis of an Electronic Conference of The Mountain Forum, 13 April - May 18, 1998.

[8] Mustapha, N, A. Azman, I. Ibrahim, Y. "Barriers to Community Participation in Tourism Development in Island Destination," in Tourism Outlook Conference on Tourism, Leisure and Global Change, p. TOC-90, 2014.

[9] Yusiana, L, S. Nurishjah, S. Soedharma, D. "Landscape Planning for Sustainable Coastal Tourism in TelukKonga, East Flores, East Nusa Tenggara (In Indonesian)," Journal of Landskap Indonesia, III (2), pp 66-72, 2011.

[10] Kelvin, J. "Coastal Forest and Its Environment Effectiveness in Reducing Run-Up Tsunami based on Comcot Model (Case Study: Tsunami Pangandaran July 17, 2006), (In Indonesian).” Padjadjaran University, Bandung. 2015.

[11] Husrin S, Kelvin J, Putra A., Prihantono J., Cara Y, Hani A. "Assessment on the characteristics and the damping performance of coastal forests in Pangandaran after the 2006 Java Tsunami," International Symposium on Earthquake and Disaster Mitigation. 2013

[12] DKP, KabupatenCiamis. "Coastal Zone Management Plans in Ciamis Regency 2012 (In Indonesian)." LaporanAkhir. Ciamis (ID). 2012.

\section{Author Profile}

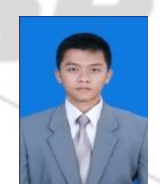

Marine KenziMartasugandareceived his Bachelor degrees in Marine Science,UniversitasPadjadjaran in 2012 and is a Master Candidate of Regional Planning Science in Institut Pertanian Bogor. $\mathrm{He}$ is also a founder and a commissionaire of KOMITMEN Research Group. His work has beenpublished in Energy Procedia.

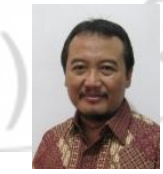

BoediTjahjonoholds a Ph.D in Geography from UniversitéBlaise Pascal de ClemontFerrand, France in 1998. He joined Bogor Agricultural University as a lecturer in 1987. His research focused on the application of remote sensing on geomorphology, mitigation and land degradation, which has been widely publishedin Energy Procediaand other journals of remote sensing, mitigation and land degradation.

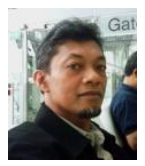

FredinanYulianda holds a Ph.D in Coastal and Ocean Resource Management from Institut Pertanian Bogor in 2003. Since 1982 he became a lecturer at the Department of Coastal and Ocean Resource Management inInstitut Pertanian Bogor. His research focused on waters conservation and ecotourism, conservation of water resources, aquatic ecotourism and aquatic ecology, which has been widely published both in national and international journals. 